Representations

of the East:

Orientalism in

Emily Eden's

\section{Travel Writing}

Leviathan: Interdisciplinary Journal in English

No. 2, 60-70

(c) The Journal Editors 2018

Reprints and permissions:

http://ojs.statsbiblioteket.dk/index.php/lev

DOI: 10.7146/lev.v0i2.104691

Recommendation: Mark Ølholm Eaton

(engme@cc.au.dk)

'The British Way': British Values, Norms and Institutions in a Rapidly Evolving World

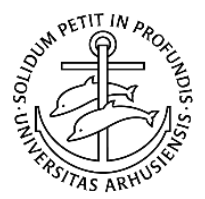

Amalie Due Svendsen

\begin{abstract}
The publication of Orientalism by Edward W. Said in 1978 gave rise to a new area of studies examining how representations of the East were influenced by an Orientalist discourse, which functioned to maintain and justify Western hegemony. Emily Eden's letters from her travels in Colonial India are examples of such representations, as they depict her meeting with and perception of the colonial Other. I argue that Eden's writing displays Orientalism, as she tends to dissociate herself from the Indians through othering, in order to preserve her national identity. However, Eden's letters are distinguished from other Orientalist travel writing in the sense that she does not articulate justification of Western superiority. Thus, I argue, that the Orientalist discourse demonstrated in Eden's letters serves the personal purpose of selfdefinition rather than the political purpose of justifying colonial rule.
\end{abstract}

Keywords: Orientalism; othering; discourse; travel writing; Colonial India; the colonial Other; 'The British Way'

Corresponding author: Amalie Due Svendsen (amaliedue@outlook.dk)

Department of English, Aarhus University 


\section{Introduction}

Since its publication in 1978, Edward W. Said's book Orientalism has drawn massive attention to Western representations of the East. In Orientalism, Said highlights a Western discourse that is manifested in a tendency to portray the Orient and its peoples as underdeveloped and inferior in contrast to the civilized West, which has helped to maintain Western hegemony. Travel writing from the British colonies is an interesting source, when discussing such representations of the East, as these narratives provide insight into the cultural meetings between the British and the 'other' revealing how the East was perceived by its colonizers. According to Indira Ghose 'criticism of travel writing has traditionally fallen prey to the mimetic fallacy' meaning that such accounts were 'seen as a transparent reflection of the reality of other cultures' (2). Recent critics, however, are moving away from this approach, as it is increasingly acknowledged that travel writing is 'a textual construction, an interpretation, not a reflection of reality' (Ghose 2). Emily Eden's letters from India are examples of such textual constructions, as they contain personal observations of the meeting between the British and the Indians during British colonial rule.

Eden's letters were written in the late 1830s, while she accompanied her brother, the GovernorGeneral, on a journey in the upper provinces of India. About 30 years later, these were published in two books, Up the Country (UC) from 1867 and Letters from India (LI) from 1872, containing letters primarily to her sister, but also other family members and friends. Eden makes a particularly interesting narrator when it comes to representations of the East, as her publications were very popular and widely read by the Victorians (Ghose 74). Thus, these textual constructions must have had some influence on the British perception of India.

The aim of this article is to critically examine to what extent and in what ways Eden's letters contribute to the Orientalist discourse as defined in Edward W. Said's Orientalism (1978). I argue that Eden's travel writing in certain respects provides an orientalist depiction of India because of Eden's tendency to dissociate herself from the Indians to preserve her national identity. However, I will also argue the source contains reflections of a different character as well, which distinguish Eden from the Orientalist viewpoint, as they express a detachment from the belief in Western superiority. To account for this complexity, my analysis will be divided into two sections; the first examining the evidence and arguments situating Eden as an orientalist writer; and the second investigating the parts of the letters suggesting that she is less influenced by the orientalist discourse than other travel narrators.

\section{Orientalism and Otherness}

Orientalism can be defined as a tendency in Western representations of the East. In 1978 Edward W. Said published Orientalism, in which he explains this tendency in Foucauldian terms as a 'mode of 
discourse with supporting institutions, vocabulary, scholarship, doctrines, even colonial bureaucracies and colonial styles' (1-2). This discourse dominated the representation and conception of the Orient, as the ideas tied to this viewpoint 'explained the behaviour of Orientals; they supplied Orientals with a mentality, a genealogy, an atmosphere; [and] most important they allowed Europeans to deal with and even to see Orientals as a phenomenon possessing regular characteristics' (42). Thus, an Orientalist viewpoint places certain boundaries on the spectator's perception of the East.

Said defines Orientalism as a complex phenomenon with more meanings. He starts by presenting three of these. Firstly, Orientalism is as an academic field, in which the Orient is studied and taught by Orientalists (2). Secondly, it is a 'style of thought', which is based on the distinction between East and West (2). This distinction has been so widely accepted that it has served as 'starting point for elaborate theories, epics, novels, social description and political accounts concerning the Orient' (2). Thirdly, Orientalism is 'a Western style for dominating, restructuring, and having authority over the Orient' (3). Thus, Said suggests that Orientalism has served the purpose of maintaining Western power and hegemony over the East (5). The West was 'always in a position of strength', and this position was justified by the perception of the Orientals as 'irrational, depraved (fallen), childlike, "different"” in contrast to the 'rational, virtuous, mature, "normal”' Europeans (40). These characteristics shape the image of an underdeveloped and uncivilized East, a constructed knowledge of the Orient, which has helped legitimize Western dominance and colonization.

An important implication of the Orientalist discourse is that it 'has helped to define Europe' (1). The image of the strange and unfamiliar oriental 'Other' has provided a contrast to Europe, which has reinforced the European culture and identity (89). The relationship between identity formation and otherness is further stressed by Peter Sahlin, who states that national identity is defined 'by the social or territorial boundaries drawn to distinguish the collective self and its implicit negation, the other' (Colley 311). Thus, the meeting with other cultures and the confrontation with otherness strengthen national identity, as expressed by Linda Colley: 'we usually decide who we are by reference to who and what we are not' (311).

\section{Orientalist Traits in Emily Eden's Travel Writing}

\section{The Unwilling Traveller}

Emily Eden (1797-1869) set sail for India in October 1835 accompanied by her sister, Fanny, and her brother, the newly appointed Governor General of India, Lord George Auckland. The purpose of Eden's travel was to assist her brother on an extensive diplomatic tour, where the Governor General's mission was to strengthen British connections to native princes and other allies in Northern India. Eden was responsible for the management of the household and performed the role of the Senior First Lady at official occasions. Thus, her special positon provides a unique insight into the core of 
Victorian imperial rule in India (Poon 455). Eden's letters are written to her friends and family (in particular her sister) in England, and they do not pretend to contain any specialized knowledge of India or the Indian people. They are simply a collection of experiences and personal reflections on these. Thus, Eden stands in contrast to other travel writers, who intended to educate their reader on the Indian country, such as Marianne Postans in Western India in 1838.

The letters of Eden draw an unusual picture of a traveller with no desire to travel, as she expresses a constant underlying discomfort with travelling and a longing for England. This is illustrated by the following quote emphasising her personal distress with being in India: 'I do say, that for a person who required nothing but to be allowed the undisturbed enjoyment of that small Greenwich house and garden, with all its little Cockney pleasures and pursuits, I have been very hardly treated and rather overworked' (UC 12). This reluctance to travel is also demonstrated in her refusal of seeking knowledge about India as she states 'I never ask questions, I hate information' (UC 62). Eden's state of mind seems quite strange compared to the curious attitude of the usual traveller, and it creates a sense of distance to her experiences in India, which is present throughout her writing. This distance is further emphasised by her writing style, which has a very humoristic (and sometimes ironic) tone when describing the party’s encounters with the Indians. The cultural meeting between the Indians and the English is thus made an object of comical representation. For instance, when a native painter is sketching her brother, she notes

if my drawing looked as odd to him as his did to me, he must have formed a mean idea of the arts in England. They put full eyes into a profile, and give hardly any shade. They paint their own people with European complexions, so that ours are a great puzzle to them, because we are so white (UC 228)

Indirectly and in a humoristic way, Eden declares that she is not very fond of Indian art; the difference from European (and familiar) art makes it unappealing to her. This letter thus becomes a representation of the otherness of the Indians - an otherness from which she attempts to distance herself.

\section{Stereotypes and Generalizations}

Eden further distinguishes herself (and the English in general) from the natives through the attribution of certain characteristics to the Indians. In one letter to her sister, she emphasises the lazy character of the natives, as she ironically writes

I must do the Hindus the honour to say that they make as many holidays out of one year as most people do out of ten; and I am not sure whether a small importation of Hindus would not be acceptable to you, to accompany your boys to school as to regulate their schooldays. It would be a safeguard against their being overworked (UC 22) 
As Eden contrasts the Hindus with her sister's English children, she constructs a negative stereotype of the natives, who are collectively represented as lazy compared to the hardworking English. A similar stereotype is presented in a description of her Indian maid: 'she is very much (as all the uneducated natives are) like a child of three years old in feelings and intellect' (LI 165). This depiction confirms Said's notion of the Orientals being perceived as 'childlike' opposite to the 'mature' Europeans. Eden's view of the maid is generalized to apply to 'all the uneducated natives', which I argue situates her as an Orientalist writer making 'every observable detail a generalization and out of every generalization an immutable law about the Oriental nature, temperament, mentality, custom or type' (Said 86). This is supported by Angelina Poon, who states that 'Eden constructs knowledge of Indian society by delineating differences between Englishness and Indianness’ (456).

Muireann O’Cinneide draws attention to another kind of generalisation in Eden’s letters, as she observes Eden's tendency to 'fit what she sees into a literary, not factual, discourse' (8). For instance, Eden finds the Prince of Lucknow's palace to be 'quite as Arabian-Nightish as I meant it to be' (O’Cinneide 8; UC 61). Similarly, she observes that the King of Delhi's palace 'looks like an exaggerated scene of Timour the Tartar', referring to Matthew Lewis' dramatic play about the Khan of the Afghan Tartars (UC 95). According to O'Cinneide, this tendency seems to 'accommodate a classic model of Orientalism', where Europeans contextualise and ascribe certain characteristics to the natives through the literary and cultural conventions of the West (8). This tendency is also highlighted by Pamela D. Toler, who states that Arabian Nights 'set a standard against which direct experience of the Orient was measured' in the Victorian period (13). This, I argue, links to Said's notion of 'textual attitude': the faulty idea that what is learned from books and texts can be literally applied to reality (93). Said notes that a situation favouring textual attitude is 'when a human being confronts at close quarters something relatively unknown and threatening and previously distant' (93). Eden stands in this position, as she is encountering a country and a culture with which she has had no previous contact. In this encounter, she applies and generalizes depictions from her literary knowledge, like Arabian Nights and Timour the Tartar, to reality, and thus she constructs a stereotypical representation of India.

\section{The Picturesque}

Eden's distance to her experiences in India is further emphasised in her continuous focus on the picturesque. The picturesque is defined as an aesthetic ideal concerned with the tension between the beautiful and the sublime: 'views seen as being artistic but containing elements of wildness or irregularity' (Tate). In Women Travellers in Colonial India, Ghose states that artists depicting the Indian picturesque, especially the Daniells, 'were enormously influential in defining the early nineteenth-century view of India' (40). She furthermore claims that 'the search for the Indian picturesque was a part of the project of Orientalism' as it depicted the East as 'timeless and 
immutable' (40). This is demonstrated by the aesthetic movement's nostalgic view of the Orient, making old ruins and tombs the main objects of paintings (40). The OED further underpins this, as the picturesque is defined as something 'pretty in an undeveloped or old-fashioned way' (OED). Thus, the picturesque ideal connects to Said's notion of the Western depiction of the Orient as underdeveloped and uncivilized.

Despite Ghose's chapter on Emily Eden, she does not comment on the role of the picturesque in Eden's writing. However, I will argue that it plays a central role in her depiction of the East as she refers to the picturesque several times. The term is only rarely applied to the landscape but frequently used to describe the Indian people. One example is when Eden and her sister are out sketching: 'F. [Fanny] and I had two very picturesque camels and camel-drivers to sketch in the morning' (UC 14). In this example, the natives become motives rather than people, as the sketching frames them and makes them aesthetic objects. This framing can be seen as a process of detachment from the Oriental other. David Punter supports this in his analysis of the relationship between the picturesque and the other, as referred to by Ghose: 'The picturesque worked to detach the traveller from the scene and to contain the threat posed by the other by arranging it into an aesthetic frame' (47-48). Eden's detachment through the picturesque is further emphasised in another letter, in which she observes some natives passing by in carriages: 'Every figure one passes looks strange and picturesque. There are moments when a feeling of desperation comes over me to think that I must dream this dream, so distinct from all my past life' (LI 94). The 'strange and picturesque' is connected to something uncomfortable, as it seems to provoke 'a feeling of desperation'. Thus, the picturesque is again tied to the Oriental other, who poses a threat to the known and familiar because of their otherness.

\section{Orientalism and National Identity}

The analysis above establishes that Eden's letters do contain some degree of Orientalism in her representation of India, and that she tends to detach herself from the native people through stereotypes, textual attitude, and aesthetic framing throughout the narrative. The cause of this detachment can be found in Eden's need to preserve her national identity. As Poon states: ‘Eden’s identity as an Englishwoman is crucially dependent on the maintenance of her position as an outsider' (457). To illustrate, Eden's concern with remaining English is expressed when she comments on the Englishmen who have "gone native” in India: 'their poor manners are utterly gone - jungled out of them' (Poon 458; UC 70). Thus, she observes that engaging with the Indians will disrupt one’s English identity. Correspondingly, O’Cinneide argues that Eden’s disinterest and detachment serves to leave her Englishness 'uncompromised': 'the more she figures herself as actually involved in India, the further away she grows from the securities of English identity and the familial bonds her writing continually seeks to reinforce' (9). 
Eden's detachment creates a dichotomy between the English and the Indians, where the first are perceived as normal and the second as strange. This dichotomy is illustrated when Eden reflects on an English ball where European soldiers (instead of native, turbaned servants) were dressed up as English footmen making the ball resemble those in England. Here Eden notes that 'it is very odd how sometimes the sudden recurrence of some common English custom shows the unnatural state of things in which we live' (UC 109). The contrast between the English and the Indians, as highlighted here, seems to reinforce Eden's sense of Englishness. This links to Sencindiver et al.'s notions on otherness in Otherness: a multilateral perspective, where it is stated that othering functions 'as a mirror to stabilize the colonialist's inverted self-image' as the other provides the 'limits against which the self can be defined' $(22,17)$. Eden thus uses othering to detach herself from the Oriental Other and to delineate her national and cultural identity.

\section{Nuances in Eden's Orientalism}

\section{Questioning Western Superiority?}

Based on the analysis above, it would be easy to jump to the conclusion that Eden's travel writing is an Orientalist representation of India. That conclusion would however not account for the fact that the letters also contain reflections which suggest that Eden does not hold an exclusively discursive perception of the East. To begin with, the letters distinguish themselves from other Victorian travel writing of India, because the English (or British) are not always displayed as culturally superior. One travel account reflecting a firm belief in British superiority is Postans’ Western India in 1838. In her introduction, Postans proclaims that 'India is making very rapid advancements in general improvement; and although the mass of the people yet unhappily remain sunk in the deepest barbarism, a change is taking place among the gentry, which will produce results of the highest interest' (vii). As this quote implies, Western India in 1838 shows great concern for the 'improvement' of the country and its native population, which reflects the Orientalist discourse of perceiving the oriental other as underdeveloped, uncivilised, and in need of Western guidance to rise from the state of 'barbarism'. Thus, Postans demonstrates an Orientalist view of India, situating the British (and Europeans) as the bearers of the torch of civilization, which justifies colonial rule.

In contrast, Eden's writing presents a more ambiguous attitude towards British presence in India. As stated above she does attribute certain negative traits to the Indians, but her representation of the British is not purely positive either. This, I will argue, is reflected in one of Eden's few reflections on the position of the colonizers:

Twenty years ago no European had ever been here, and there we were, with the band playing the "Puritani” and “Masaniello”, and eating salmon from Scotland, and sardines from the Mediterranean, and observing that St. Cloup’s potage à la Julienne was perhaps 
better than his other soups, and that some of the ladies' sleeves were too tight according to the overland fashions for March, \&c. ; and all this in the face of those high hills, some of which have remained untrodden since the creation, and we, 105 Europeans, being surrounded by at least 3000 mountaineers, who, wrapped up in their hill blankets, looked at what we call our polite amusements, and bowed to the ground if a European came near them. I sometimes wonder they do not cut all our heads off, and say nothing more about it (UC 293-294)

Eden observes that British rule in India is a relatively new invention, and she displays awareness of the fact that the British, despite their dominance, are still a minority compared to the native population - a minority that could easily be overpowered. Poon makes the same observation as she states: 'this passage ostensibly emphasises the vulnerability of the British' (460). Furthermore, Poon argues that the passage 'also represents the affection of ultimate power, of Western superiority and racial dominance' (460). I disagree with this analysis. On the contrary, I argue that Eden at this point of her travel narrative positions herself as an outsider, observing the absurdity of the British presence in India. It appears that she for a moment takes the perspective of the natives 'wrapped up in their hill blankets', and through their eyes observes the strangeness of the 'polite amusements' of the British. The European culture, manifested in Scottish salmon, Mediterranean sardines and French music, suddenly appears silly and out of context in the Indian scenery. Earlier I described how Eden's ironic tone served to distinguish herself from the natives, but in this case, self-mockery creates a distance to her own countrymen, and thus a distance to the colonial rule she herself is actively engaged in. Ghose supports this argument stating that 'in the ironic distance from her own culture that the text enacts, lurks a suspicion of the absurdity and transience of British colonial rule' (84). Thus, rather than emphasising Western superiority, this passage demonstrates a slight dissociation from colonial rule, which distinguishes Eden from the Orientalist discourse.

A similar dissociation is demonstrated, when Eden in one letter, recently confronted with the consequences of the Agra Famine, reflects upon the roles of the colonizer and the colonized (Dando 45):

An odd world certainly! Perhaps two thousand years hence, when the art of steam has been forgotten, and nobody can exactly make out the meaning of the old English word “mail-coach”, some black Govenor-General of England will go and look at some ruins, and doubt whether London was ever a large town, and will feed some white-looking skeletons, and say what distress must the poor creatures be in; they will really eat rice and curry; and his sister will write to her Mary D. at New Delhi, and explain to her with great care what snow is, and how the natives wear bonnets, and then, of course, mention that she wants to go home (UC 66-67) 
In this passage, Eden shows awareness of herself being embedded in a historical period. She imagines a future where the roles of colonizer and colonized have been reversed, which suggests an idea of a certain amount of coincidence in the present state of things. The presentation of a potential alternative world order suggests that Eden does not see Western superiority and dominance as self-evident, and that the current power balance of East and West might not be static - someday the English might find themselves in the positon of 'the natives'. Ghose supports this analysis. She argues that 'neither the innate superiority of the achievements of Western civilization ("when the art of steam has been forgotten”) nor that of the British race ("some black Governor-General...will feed some white-looing skeletons”) are assured' (84). Therefore, I argue that Eden's writing is distinguished from other Orientalists' (such as Postans'), because she does not articulate the justification of Western authority over the East.

\section{Otherness or Sameness?}

In the first part of the paper, I emphasised Eden's tendency to detach herself from the natives through othering. Yet, her writing does contain a few examples of the opposite, namely passages where she decreases the distance between the English and the Indians. This is illustrated by the dispute, which Ghose refers to as the 'shoe-controversy' (81). When the party is visiting the Maharajah Runjeet Singh, the problem of whether the Governor-General should remove his shoes when entering a temple arises. Many in the party are against this, because they see it as a symbolic degradation. Eden however sees it in a different perspective: 'Runjeet takes off his shoes and stoops down and puts some dust on his forehead; it amounts to taking of a hat, and only answers to the same respect that we should wish anybody to pay on entering one of our own churches' (215). Eden recognizes that despite the different religions of the English and the Indians, some of the rituals revolving around religious practice are alike. This acknowledgement of similarity reduces the depiction of otherness, and stands in contrast to other of Eden's descriptions presenting the Indians as 'strange'. Despite many instances of othering, Eden's tendency to dissociate herself from the Indian culture is thus not constant throughout her narrative.

\section{Conclusion}

The analysis above reveals the complexity of Eden's travel writing. Some letters clearly represent an Orientalist 'style of thought' (as defined by Said) as they demonstrate a perception of India based on generalizations, textual attitude, and aesthetic framing. This approach to the Indians highlights their contrast to the English, which detaches Eden from her experiences and helps to preserve her national identity. Thus, Eden's letters provide a small-scale example of the effects of Orientalism, which, according to Said, helped to define Europe. Yet, the letters do not represent Said's second notion on 
Orientalism: 'a Western style for dominating'. On the contrary, the few comments on the relationship between colonizer and colonized suggest a slight dissociation from colonial rule. The lack of emphasis on Western superiority and justification of imperialism thus separates her from other Orientalist writers such as Marianne Postans. Furthermore, there are examples where Eden reduces the otherness of the Indians by observing the similarities between the two cultures, which demonstrates that although her writing is generally dominated by dissociation, this dissociation is not maintained in all encounters with the Indians.

Consequently, Eden's letters constitute a complex representation of India. A representation which on the one hand paints the picture of a strange Oriental Other, but which on the other hand, despite her position, shows no justification of Western authority over the East. This suggests that the Orientalist depictions in Eden's letters serve a personal purpose of self-definition, rather than the political or moral purpose of justifying colonial rule. This conclusion, based on a single travel narrative, could be used as a starting point for more comprehensive research on travel writing from the colonies, investigating other Orientalist representations of the East and how these to different degrees functioned to maintain both the empire and the travellers' self-understanding. This might allow conclusions on the broader effects of the discourse of orientalism. 


\section{Works Cited}

Colley, Linda. 'Britishness and Otherness: An Argument'. Journal of British Studies, vol. 31, no. 4, 1992, p. 311, www.jstor.org/stable/175883. Accessed 9 November 2017.

Dando, William. A., editor. Food and Famine in the 21 ${ }^{\text {st }}$ Century. ABC-CLIO, LLC, 2012.

Eden, Emily. Letters from India, vol. 1. Richard Bentley and Son, 1872.

Eden, Emily. Up the Country. Richard Bentley, 1867.

Ghose, Indira. The Power of the Female Gaze: Women Travellers in Colonial India. Oxford University Press, 1998.

O’Cinneide, Muireann. 'Oriental Interests, Interesting Orients: Class, Authority, and the Reception of Knowledge in Victorian Women's Travel Writing'. Critical Survey, vol. 21, no. 1, 2009, pp. 8-9, doi:10.3167/cs.2009.210102. Accessed 15 December 2017.

Oxford English Dictionary. 'Picturesque, adj. and n.’. http://www.oed.com.ez.statsbiblioteket.dk:2048/view/Entry/143510?rskey=enI8kw\&result=1\&is Advanced=false\#eid. Accessed 12 December 2017.

Poon, Angelina. 'Seeing Double: performing English identity and imperial duty in Emily Eden's Up the Country and Harriet Martineau's British Rule in India'. Women's Writing, vol. 12, no. 3, 2005, pp. 455-460, doi:10.1080/09699080500200274. Accessed 10 December 2017.

Postans, Marianne. Western India in 1838, vol.1.Saunders and Otley, 1839.

Said, Edward. Orientalism. Penguin Classics, 2003.

Sencindiver, Susan et al. Otherness: A Multilateral Perspective. Peter Land, Internationale Verlag der Wissenschaften, 2011.

Tate Museum. 'Art term: Picturesque’. www.tate.org.uk/art/art-terms/p/picturesque. Accessed 18 December 2017. 